\title{
HPLC Method Development and Validation for the Quantification of Related Impurities in Testosterone Cypionate Active Pharmaceutical Ingredient
}

\author{
Amber Bharti ${ }^{1,2, *}$, Ravindra Motiram Kumbhare ${ }^{3}$, Christine Jeyaseelan' \\ 1Department of Chemistry, Amity Institute of Applied Sciences, Amity University, Noida, Uttar Pradesh, INDIA. \\ ${ }^{2}$ Ipca Laborotaries Ltd., GIDC Estate, Nandesari, Vadodara, Gujarat, INDIA. \\ ${ }^{3}$ Fluoro-Agrochemicals Department, CSIR-Indian Institute of Chemical Technology, Tarnaka, Hyderabad, Telangana, INDIA.
}

\begin{abstract}
Aim: The purpose of this research study, is to develop and validate a reverse phase HPLC test method for detecting relevant impurities in Testosterone cypionate (TCY). Materials and Methods: The chromatographic system for separation of related impurities were achieved in Zorbax XDB-C8 $(15 \mathrm{~cm} \times 4.6 \mathrm{~mm}), 5$ micron HPLC column utilising gradient elution technique. Water was selected as solvent-A and Acetonitrile was preferred as solvent- $B$ for mobile phase. The method is gradient technique. Column heater was kept constant at $35^{\circ} \mathrm{C}$; the rate of flow was $1.2 \mathrm{~mL}$ per min; volume of injection was $20 \mu \mathrm{L}$ and $240 \mathrm{~nm}$ was set for detector wavelength. Results: The \% recovery was in the range of $95.6 \%$ to $108.7 \%$ for all impurities. The result of correlation coefficient were higher than 0.98 . Testosterone is the major degradants obtained from forced degradation study. Conclusion: The created method can be utilise in quality control testing on a regular basis for the analysis of Testosterone cypionate.
\end{abstract}

Key words: Testosterone cypionate, Testosterone replacement therapy, Male hypogonadism, HPLC, Impurity profiling.

\section{INTRODUCTION}

Testosterone is a natural sex hormone in male that helps males to develop their sex organs and improve their secondary sexual characteristics. TCY (testosterone cypionate) is an anabolic-androgenic steroid and manufactured by esterifying Testosterone. This type of product has a higher lipid solubility, which delays medication release into circulation and improves pharmacological action. ${ }^{1}$ TCY is commercially known as Depo-testosterone and available as an oily based injectable solution. ${ }^{2}$ Approximately $200 \mathrm{mg}$ of TCY is injected intramuscularly ones in every 2 to 3 weeks to compensate the serum testosterone level, which occurs due to improper function of testis, results in male hypogonadism..$^{3-6}$ It is commonly used to treat male hypogonadism, which causes erectile dysfunction, delayed puberty, osteoporosis, a decline in ejaculate volume, and an rise in body fat. ${ }^{7-12}$

Several scientific papers are published on the applicability of several assement techniques for the detection and monitoring of anabolic-androgenic steroids and its metabolite in biological matrices. ${ }^{13-17}$

HPLC method development and validation for testosterone Cypionate, Propioante and other testosterone esters in drug substance and oil based injectables have also been studied. ${ }^{18-20}$ In addition, the assay method for testosterone cypionate by Gas chromatography with Flame ionization detector has been described in United States Pharmacopoeia. ${ }^{21}$ Various pharmacopoeias such as IP, Ph.Eur, USP and JP have yet not reported the chromatographic HPLC test method for the assessment of related impurities in
Submission Date: 18-08-2020; Revision Date: 09-08-2021; Accepted Date: 27-09-2021.

DOI: 10.5530/ijper.56.1.28 Correspondence: Mr. Amber Bharti, Department of chemistry, Amity Institute of Applied Sciences, Amity University, Uttar Pradesh, Noida-201303, Uttar Pradesh, INDIA.

Email: bharti_amber@ rediffmail.com

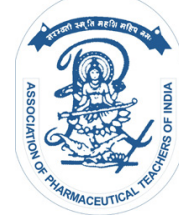

www.ijper.org 
TCY. Hence it is critical to establish stability reflecting, specific and accurate test method for the assessment of possible impurities in TCY. Current project describes the development of an HPLC technique for impurity profiling, forced degradation, and TCY method validation in accordance with current $\mathrm{ICH}$ criteria. $22-25$

\section{MATERIALS AND METHODS}

\section{Materials and chemicals}

Sample of TCY and Imp-1 to Imp-6 were obtained from Ipca laborotaries Ltd. Water for the analysis was acquired from Millipore's Milli-Q plus water purification equipment (HPLC grade) (Bedford, USA). Merck India supplied the acetonitrile (Mumbai, India).

\section{HPLC conditions}

Waters HPLC (2695) with UV detector (2487) and PDA detector (2996) (Waters Corporation, USA); a photo stability chamber model NEC-104RTS (Newtronic, Mumbai, India), where utilise for the study.

In this study, the chromatographic column Zorbax XDB-C8 (15 cm x $4.6 \mathrm{~mm}), 5$ micron was utilised (Agilent, santa Clara, United States). Water was selected as solvent-A and Acetonitrile was preferred as solvent-B for mobile phase. The method is gradient technique. Column heater was kept constant at $35^{\circ} \mathrm{C}$; the rate of flow was $1.2 \mathrm{~mL}$ per min; volume of injection was $20 \mu \mathrm{L}$ and $240 \mathrm{~nm}$ was set for detector wavelength and the sample temperature was $25^{\circ} \mathrm{C}$. The diluent was a 30:70 (v/v) mixture of water and acetonitrile. Table 1 shows the gradient programme.

\section{Preparation of sample, stock solution for validation and forced degradation samples}

Transferring around $20.0 \mathrm{mg}$ of TCY sample into a $50 \mathrm{~mL}$ volumetric flask, $10 \mathrm{~mL}$ of acetonitrile was added, sonicated for $1.0 \mathrm{~min}$, and made up to the volume with diluent yielded a $400 \mu \mathrm{g} / \mathrm{mL}$ test sample of TCY. Transferring around $20.0 \mathrm{mg}$ of TCY sample and all impurities (imp-1 to imp-6) into 7 separate

\begin{tabular}{|c|c|c|}
\hline \multicolumn{3}{|c|}{ Table 1: Linear gradient program. } \\
\hline Time/minutes & Solvent-A, $\%$ & Solvent-B, $\%$ \\
\hline 0 & 50 & 50 \\
\hline 5 & 50 & 50 \\
\hline 20 & 20 & 80 \\
\hline 30 & 20 & 80 \\
\hline 35 & 50 & 50 \\
\hline 45 & 50 & 50 \\
\hline
\end{tabular}

$25 \mathrm{~mL}$ volumetric flasks, adding $10 \mathrm{~mL}$ of acetonitrile, sonicating for $1.0 \mathrm{~min}$, and making up to the volume with diluent yielded an $800 \mu \mathrm{g} / \mathrm{mL}$ individual stock solution. $0.75 \mathrm{~mL}$ of each of the above separate stock solutions was transferred to a $20 \mathrm{~mL}$ volumetric flask and diluent was added to make up the volume. Standard stock solution $(30.0 \mu \mathrm{g} / \mathrm{mL})$ was indicated on this solution. Other required solutions of various concentrations were created for validation using above standard stock solutions.

Each sample weighed around $20 \mathrm{mg}$ and was divided into three $50 \mathrm{~mL}$ volumetric flasks designated 1,2, and 3 . Into each volumetric $10 \mathrm{~mL}$ acetonitrile was added and the sample was dissolved. In volumetric flasks 1, 2, and 3, $5 \mathrm{~mL}$ of $0.5 \mathrm{~N}$ hydrochloric acid solution, $1 \mathrm{~mL}$ of $0.5 \mathrm{~N}$ sodium hydroxide, and $2 \mathrm{~mL}$ of 5.0 percent hydrogen peroxide solution were added, respectively. The flasks were held at $60^{\circ} \mathrm{C}$ in a water heater bath for $2 \mathrm{hr}, 20 \mathrm{~min}$, and $4 \mathrm{hr}$, respectively. In volumetric flasks 1 and 2, the excess acid or base was neutralised and diluent was added up to the mark. Blank solutions were generated in the same way. Thermal deterioration of a solid sample was carried out at $80^{\circ} \mathrm{C}$ for $48 \mathrm{hr}$. Photolytic deterioration was achieved by spreading the sample on a petri dish and exposing it to 1.2 million Lux hours of white fluorecent light and $200 \mathrm{Wh} / \mathrm{m} 2$ of Ultra violet light in a photo stability chamber.

\section{RESULTS AND DISCUSSION}

\section{HPLC method development}

The goal of the chromatographic procedure was to obtain a baseline separation between all relevant impurities and to elute TCY before $30.0 \mathrm{~min}$ in order to shorten the time duration. The elution time of impurities was used to designate them. Structural details of TCY and its impurities are listed in Table 2. TCY and its possible potential impurities have a maximum wavelength of $240 \mathrm{~nm}$ as shown in Figure 1. The method development was initiated using water and acetonitrile in a combination of $(50: 50, \mathrm{v} / \mathrm{v})$ by isocratic elution method, using Zorbax XDB-C8 (15 cm x $4.6 \mathrm{~mm}) 5$ micron column. The peak of TCY was not eluted upto $100 \mathrm{~min}$. The mobile phase was then modified to water and acetonitrile in a combination of $(40: 60, v / v)$ in which the peak of TCY elutes at about $47.0 \mathrm{~min}$. After multiple experiments, the analysis methodolgy was finally developed using linear gradient program. Water was selected as solvent-A and Acetonitrile was preferred as solvent- $\mathrm{B}$ for mobile phase. Both the mobile phase is utelise in gradient elution procedure. The column heater was kept constant at $35^{\circ} \mathrm{C}$; the rate of flow was 


\begin{tabular}{|c|c|c|c|c|}
\hline S.no & Name & Structure & Code & Source \\
\hline 1 & Testosterone Cypionate & & TCY & Drug \\
\hline 2 & Testosterone & & Imp-1 & Process and degradation Impurity \\
\hline 3 & Androstenedione & & Imp-2 & Process impurity \\
\hline 4 & 3-Methoxy testosterone & & Imp-3 & Process impurity \\
\hline 5 & 3-Methoxy Androstenedione & & Imp-4 & Process impurity \\
\hline 6 & Testosterone Cyclopentane acetate & & Imp-5 & Process impurity \\
\hline 7 & Testosterone Cyclopentane Carbonate & & Imp-6 & Process impurity \\
\hline
\end{tabular}

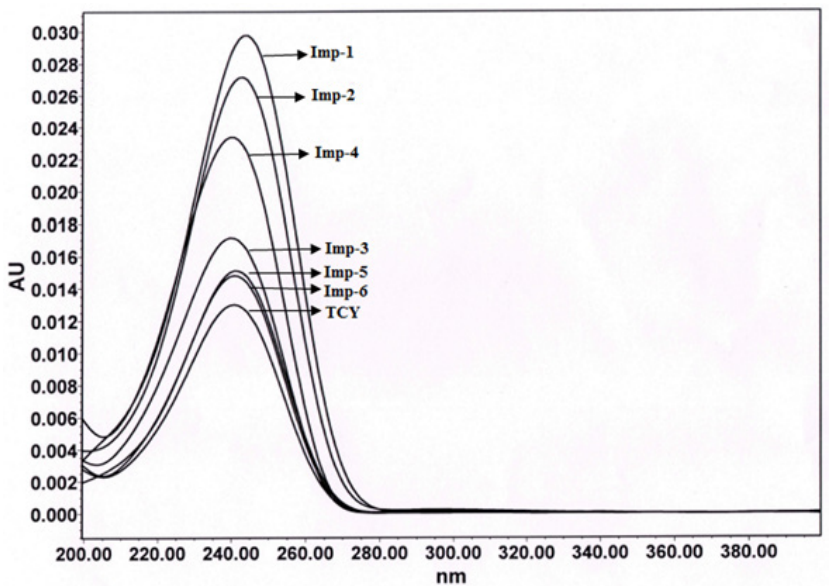

Figure 1: The $\lambda_{\max }$ of Testosterone Cypionate and its potential impurities.

$1.2 \mathrm{~mL}$ per min; volume of injection was $20 \mu \mathrm{L} ; 240$ $\mathrm{nm}$ was set for detector wavelength and the sample

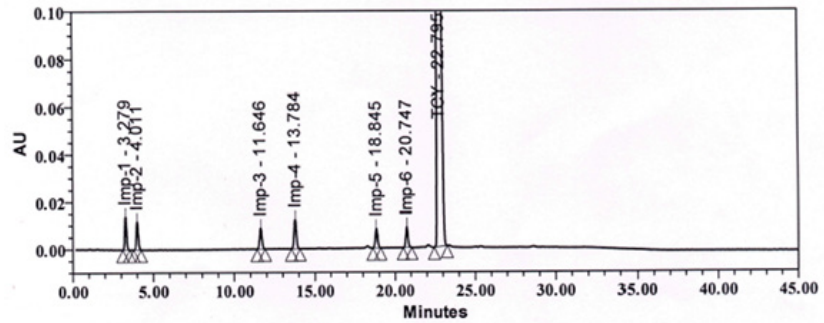

Figure 2: Chromatogram of spiked impurities in Testosterone Cypionate.

temperature was $25^{\circ} \mathrm{C}$. The TCY peak eluted at about 22 min with the base line separation of all impurities (Figure 2).

\section{Forced degradation study}

TCY was forced to detoriate in acidic, basic, thermal, oxidative, and photolytic conditions. TCY was degrade in both acidic and basic environments. Imp-1 was 
identified as the impurity generated in both situations. TCY was unaffected by oxidative, thermal, or photolytic conditions. The peak purity results of the analyte peak obtained from the Photodiode array detector in all the stress samples confirmed that method is stability indicating. The chromatograms are showed in Figure 3 and data is tabulated in Table 3.

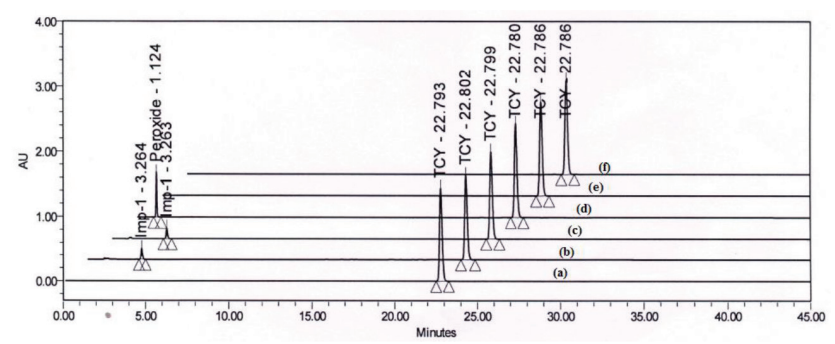

Figure 3: Chromatogram of forced degradation studies of Testosterone Cypionate: (a) control sample, (b) acid hydrolysis, (c) base hydrolysis, (d) oxidative degradation, (e) photolytic degradation, (f) thermal degradation.

\begin{tabular}{|c|c|}
\hline \multicolumn{2}{|c|}{$\begin{array}{c}\text { Table 3: Percentage of degradation under different } \\
\text { conditions. }\end{array}$} \\
\hline Condition & Degradation $\%$ \\
\hline Acidic $\left(5 \mathrm{~mL}\right.$ of $\left.0.5 \mathrm{~N} \mathrm{HCl}, 60^{\circ} \mathrm{C}, 2 \mathrm{hr}\right)$ & 6.63 \\
\hline Basic $\left(1 \mathrm{~mL}\right.$ of $\left.0.5 \mathrm{~N} \mathrm{NaOH}, 60^{\circ} \mathrm{C}, 20 \mathrm{~min}\right)$ & 7.43 \\
\hline Oxidation $\left(2 \mathrm{~mL}\right.$ of $\left.5 \% \mathrm{H} 2 \mathrm{O} 2,25^{\circ} \mathrm{C}, 4 \mathrm{hr}\right)$ & No degradation \\
\hline Thermal $\left(80^{\circ} \mathrm{C}, 48 \mathrm{hr}\right)$ & No degradation \\
\hline $\begin{array}{c}\text { Photolytic (Photolytic chamber, } 10 \text { days, } \\
\left.25^{\circ} \mathrm{C}\right)\end{array}$ & No degradation \\
\hline
\end{tabular}

\section{Method validation}

The method must be verified according to ICH criteria to ensure specificity, solution stability, sensitivity, linearity, precision, accuracy, and robustness. Table 4 contains a summary of the method validation results.

\section{Specificity}

One of the most significant parameters in HPLC method validation is specificity. It refers to the analytical method ability to distinguish between the analyte and other impurities in the sample. The specificity of the procedure was tested by injecting a blank, sample solution, and sample added with potential impurities independently. All six impurities are well segrigated from each other and TCY peak. Also, no blank interference was observed. Stress degradation analysis was also performed to assess the proposed method specificity and stability indicating properties.

\section{Solution stability}

By injecting sample solution and sample added with related impurities in a tightly closed HPLC vial at $25^{\circ} \mathrm{C}$ in a temperature controlled automated sampler, the solution integrity of TCY and impurities were investigated. Content of each impurity was checked for initial $(0 \mathrm{~h})$ and after $24 \mathrm{hr}$ and the percentage difference found was less than $10.0 \%$, demonstrating the stability of the solution upto $24 \mathrm{hr}$ at $25^{\circ} \mathrm{C}$ in the recommended diluent.

\section{Detection limit (LOD) and quantitation limit(LOQ)}

The sensitivity of the procedure is described by LOD and LOQ limit. The lower the value, the more sensitive

\begin{tabular}{|c|c|c|c|c|c|c|c|}
\hline Parameter & Imp-1 & Imp-2 & Imp-3 & Imp-4 & Imp-5 & Imp-6 & TCY \\
\hline Retention Time (RT) & 3.28 & 4.01 & 11.65 & 13.78 & 18.85 & 20.75 & 22.80 \\
\hline Relative RT & 0.14 & 0.18 & 0.51 & 0.60 & 0.83 & 0.91 & 1.0 \\
\hline Resolution & -- & 3.37 & 30.71 & 8.10 & 19.52 & 7.41 & 7.49 \\
\hline Symmetry factor & 1.17 & 1.14 & 1.06 & 1.07 & 1.10 & 1.09 & 1.20 \\
\hline Response factor & 0.76 & 0.74 & 0.83 & 0.61 & 0.94 & 0.99 & 1.0 \\
\hline Linearity & 0.9999 & 0.9997 & 0.9999 & 0.9998 & 0.9999 & 0.9998 & 0.9999 \\
\hline Detection Limit $(\mu \mathrm{g} / \mathrm{mL})$ & 0.0358 & 0.0359 & 0.0357 & 0.0358 & 0.0354 & 0.0351 & 0.0359 \\
\hline Quantitation Limit $(\mu \mathrm{g} / \mathrm{mL})$ & 0.1192 & 0.1198 & 0.1192 & 0.1194 & 0.1184 & 0.1171 & 0.1197 \\
\hline Intra-day precision ( $n=6, \%$ RSD) & 0.56 & 0.50 & 0.78 & 0.35 & 0.76 & 1.39 & -- \\
\hline $\begin{array}{c}\text { Inter-day precision } \\
(n=6, \% \text { RSD })\end{array}$ & 0.69 & 0.66 & 0.56 & 0.67 & 0.35 & 0.68 & -- \\
\hline Accuracy at QL level & 100.1 & 98.9 & 99.0 & 95.6 & 103.4 & 105.7 & -- \\
\hline Accuracy at $100 \%$ level & 99.6 & 101.1 & 100.9 & 99.3 & 101.1 & 102.7 & -- \\
\hline Accuracy at $150 \%$ level & 105.4 & 104.5 & 104.5 & 102.5 & 102.4 & 108.7 & -- \\
\hline
\end{tabular}




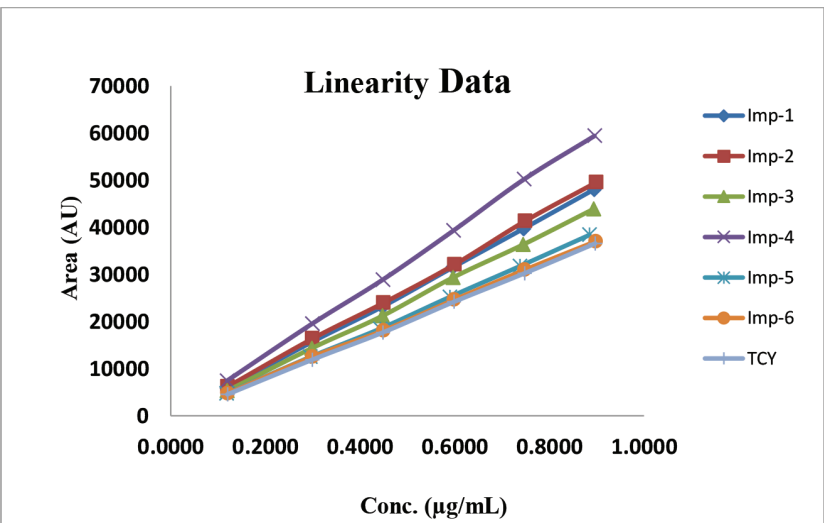

Figure 4: Linearity data of all impurities and Testosterone Cypionate.

the procedure. The LOD and LOQ for each impurity as well as TCY were calculated and found in between $0.0351 \mu \mathrm{g} / \mathrm{mL}$ to $0.0359 \mu \mathrm{g} / \mathrm{mL}$ and $0.1171 \mu \mathrm{g} / \mathrm{mL}$ to $0.1198 \mu \mathrm{g} / \mathrm{mL}$ respectively.

\section{Linearity and range}

The lease square approach was used to determine linearity for all specified impurities and drug substances from the LOQ level to the percentage of specified limit of the analyte concentration $(0.4 \mathrm{mg} / \mathrm{mL})$. The standard stock solution was further diluted to the necessary concentrations and created six different concentration. The correlation coefficients determined for all impurities were greater than 0.98 , indicating a positive link between peak areas and impurity concentrations (Figure 4).

\section{Accuracy}

Recovery tests were used to determine the accuracy of the related substances technique. Spiking known amounts of impurities in a TCY sample $(400 \mu \mathrm{g} / \mathrm{mL})$ in triplicate at the LOQ level (0.03 percent of the drug substances), at 100 percent ( 0.15 percent of the drug substances), and 150 percent (0.225 percent of the drug substances) was used to determine accuracy. The added concentration was compared to the recovered concentration to determine the recovery percentage for each impurity. The recovery percentage ranged from 95.6 percent to 108.7 percent.

\section{Precision}

Six independent preparations of TCY samples $(400 \mu \mathrm{g} / \mathrm{mL})$ spiked with 0.15 percent $(0.60 \mu \mathrm{g} / \mathrm{mL})$ of each known impurity were used to achieve the precision of the analytical test method (within the same day). The interday precision was established by performing analysis by another analysts on another instruments and on separate

\begin{tabular}{|c|c|c|c|}
\hline \multicolumn{4}{|c|}{ Table 5: Batch results. } \\
\hline Name of impurity & Batch-1 & Batch-2 & Batch-3 \\
\hline Impurity-1 & 0.12 & 0.07 & 0.10 \\
\hline Impurity-2 & 0.05 & Not detected & $\begin{array}{c}\text { Not } \\
\text { detected }\end{array}$ \\
\hline Impurity-3 & 0.07 & 0.04 & $\begin{array}{c}\text { Not } \\
\text { detected }\end{array}$ \\
\hline Impurity-4 & Not detected & 0.05 & 0.03 \\
\hline Impurity-5 & 0.07 & 0.04 & 0.07 \\
\hline Impurity-6 & 0.09 & 0.08 & $\begin{array}{c}\text { Not } \\
\text { detected }\end{array}$ \\
\hline
\end{tabular}

day. In both the precision, the percentage RSD for each impurity was found to be less than 10.0 percent.

\section{Robustness}

As per the study, even purposely adjusting the chromatographic settings (i.e. column heater, rate of flow and mobile phase composition) had no effect on the procedure. The resolution of all impurities and the TCY peak was found to be more than 2.0. This demonstrated the robustness of the method.

\section{Batch results}

Three distinct batches of testosterone Cypionate samples were subjected to the proposed HPLC technique. Imp-1 and Imp-5 was found in all the batches. The results are tabulated in Table 5 .

\section{CONCLUSION}

The HPLC test method with UV detector for the assessing of possible impurities in Testosterone Cypionate (TCY) reported in this paper is simple, precise, sensitive, accurate and linear. The validation was carried out in compliance with ICH criteria and the test method can now be utilised for routine and additional stability analysis of testosterone cypionate drug substances.

\section{ACKNOWLEDGEMENT}

The authors are greatful to the Ipca laboratories Ltd., and Amity University for providing the essential guidance.

\section{CONFLICT OF INTEREST}

The authors declare no conflict of interest. 


\section{ABBREVIATIONS}

TCY: Testosterone Cypionate; HPLC: High Performane Liquid Chromatography; USP: United States Pharmacopoeia; Ph.Eur: European Pharmacopoeia; JP: Japanese Pharmacopoeia; IP: Indian Pharmacopoeia; ICH: International Council for Harmonisation of Technical Requirement for Pharmaceuticals for Human use; UV: Ultraviolet; LOD: Limit of Detection; LOQ: Limit of Quantitation; RSD: Relative Standard deviation.

\section{REFERENCES}

1. Meireles JR, Oliveira SV, Costa-Neto AO, Cerqueira EM. Genotoxic and cytotoxic effects of testosterone cypionate (deposteron(®)). Mutat Res. 2013;753(2):72-5. doi: 10.1016/j.mrgentox.2013.02.003, PMID 23474392.

2. Shoskes JJ, Wilson MK, Spinner ML. Pharmacology of testosterone replacement therapy preparations. Transl Androl Urol. 2016;5(6):834-43. doi: 10.21037/tau.2016.07.10, PMID 28078214.

3. Schulte-Beerbühl M, Nieschlag E. Comparison of Testosterone, Dihydrotestosterone, Luteinizing Hormone, and Follicle-Stimulating Hormone in Serum after Injection of Testosterone Enanthate or Testosterone Cypionate. Fertility and Sterility. 1980;33(2):201-3. doi: 10.1016/S0015-0282(16)44543-7.

4. Nankin HR. Hormone kinetics after intramuscular testosterone cypionate. Fertil Steril. 1987;47(6):1004-9. doi: 10.1016/S0015-0282(16)59237-1, PMID 3595893.

5. Nankin HR, Lin T, Osterman J. Chronic testosterone cypionate therapy in men with secondary impotence. Fertil Steril. 1986;46(2):300-7. doi: 10.1016/ s0015-0282(16)49529-4, PMID 3525237.

6. Bhasin S, Cunningham GR, Hayes FJ, Matsumoto AM, Snyder PJ, Swerdloff RS, Montori VM. Testosterone Therapy in Adult Men with Androgen Deficiency Syndromes: An Endocrine Society Clinical Practice Guideline. The Journal of Clinical Endocrinology \& Metabolism. 2006;91(6):1995-2010. doi: 10.1210/ jc.2005-2847.

7. Jain P, Rademaker AW, Mcvary KT. Testosterone supplementation for erectile dysfunction: results of a meta-analysis. J Urol. 2000;164(2):371-5. doi: 10.1016/S0022-5347(05)67363-6, PMID 10893588.

8. Khera M. Testosterone Therapies. Urol Clin North Am. 2016;43(2):185-93. doi: 10.1016/j.ucl.2016.01.004, PMID 27132575.

9. Chatterjee R, Wood S, McGarrigle HH, Lees WR, Ralph DJ, Neild GH. A novel therapy with testosterone and sildenafil for erectile dysfunction in patients on renal dialysis or after renal transplantation. J Fam Plann Reprod Health Care. 2004;30(2):88-90. doi: 10.1783/147118904322995438, PMID 15086991.

10. Kacker R, Conners W, Zade J, Morgentaler A. Bone Mineral Density and Response to Treatment in Men Younger Than 50 Years with Testosterone
Deficiency and Sexual Dysfunction or Infertility. J Urol. 2014;191(4):1072-6. doi: 10.1016/j.juro.2013.10.070.

11. Nieschlag E, Behre HM, Bouchard P, Corrales JJ, Jones TH, Stalla GK, Webb SM, Wu FC. Testosterone replacement therapy: current trends and future directions. Hum Reprod Update. 2004;10(5):409-19. doi: 10.1093/ humupd/dmh035, PMID 15297434.

12. Nieschlag E. Testosterone treatment comes of age: new options for hypogonadal men. Clin Endocrinol (Oxf). 2006;65(3):275-81. doi: 10.1111/j.1365-2265.2006.02618.x, PMID 16918944.

13. Mitrevski BS, Wilairat P, Marriott PJ. Comprehensive two-dimensional gas chromatography improves separation and identification of anabolic agent in doping control. J Chromatogr A. 2010;1217;1:127-35.

14. Liu W, Zhang L, Fan L, Lin Z, Cai Y, Wei Z, Chen G. An improved hollow fiber solvent-stir bar microextraction for the preconcentration of anabolic steroids in biological matrix with determination by gas chromatographymass spectrometry. J Chromatogr A. 2012;1233:1-7. doi: 10.1016/j. chroma.2012.01.064, PMID 22386059.

15. Mesmer MZ, Satzger RD. Determination of anabolic steroids by HPLC with UV-vis-particle beam mass spectrometry. J Chromatogr Sci. 1997;35(1):38-42. doi: 10.1093/chromsci/35.1.38, PMID 8989871.

16. Forsdahl G, Vatne HK, Geisendorfer T, Gmeiner G. Screening of testosterone esters in human plasma. Drug Test Anal. 2013;5(11-12):826-33. doi: 10.1002/ dta.1560, PMID 24124080.

17. Guercia C, Cianciullo P, Porte C. Analysis of testosterone fatty acid esters in the digestive gland of mussels by liquid chromatography-high resolution mass spectrometry. Steroids. 2017;123:67-72. doi: 10.1016/j.steroids.2017.05.008, PMID 28502861.

18. Gonzalo-Lumbreras R, García-Miguens MA, Izquierdo-Hornillos R. HPLC method development for testosterone propionate and cipionate in oil-based injectables. J Pharm Biomed Anal. 2005;38(4):757-62. doi: 10.1016/j. jpba.2005.02.003, PMID 15967305.

19. Gupta RK, Roy RK, Anurag JAN. HPLC method development for testosterone cipionate in bulk drug and oil-based injectables. Biosci Biotechnol Res Asia. 2010;7(1):505-11.

20. Kozlik P, Tircova B. Development of the fast, simple and fully validated high performance liquid chromatographic method with diode array detector for quantification of testosterone esters in an oil-based injectable dosage form. Steroids. 2016;115:34-9. doi: 10.1016/j.steroids.2016.08.008, PMID 27521801.

21. United States Pharmacopoeia 2018. USP 41 and NF 36. Published by United State pharmacopoeia commission. 2018;3:4002-3.

22. $\mathrm{ICH}$. International Conference on Harmonisation, Stability testing of new drug substances and products. Vol. Q1A; 2003. (p. R2).

23. ICH. Q1B. International Conference on Harmonisation, Photostability testing of new drug substances and products; 1996.

24. $\mathrm{ICH}$. International conference on harmonisation, validation of analytical procedure: Text and methodology. Vol. Q2; 2005. (p. R1).

25. Blessy MR, Patel RD, Prajapati PN, Agrawal YK. Development of forced degradation and stability indicating studies of drugs-A review. J Pharm Anal. 2014;4(3):159-65. doi: 10.1016/j.jpha.2013.09.003, PMID 29403878. 
PICTORIAL ABSTRACT

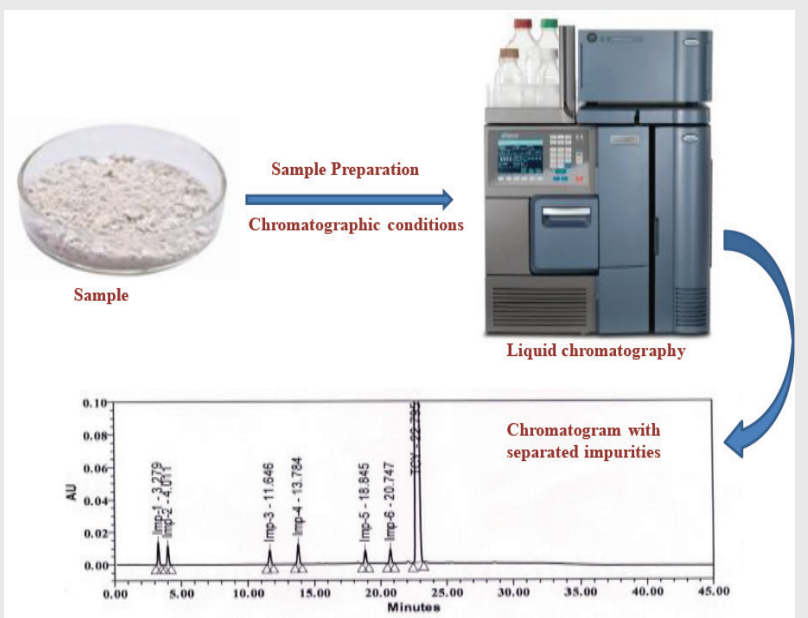

\section{SUMMARY}

- Develop stability demonstrating reverse phase HPLC test method for the determination of possible impurities in Testosterone cypionate

- Zorbax XDB-C8 $(15 \mathrm{~cm} \times 4.6 \mathrm{~mm}), 5$ micron column was used

- Water was selected as solvent-A and Acetonitrile was preferred as solvent- $B$ for mobile phase

- $\quad \mathrm{ICH}$ guidelines was used to validate the method

- Forced degradation was performed

- The method is useful for routine quality control testing

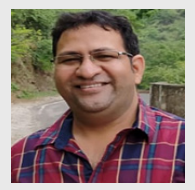

\section{About Authors}

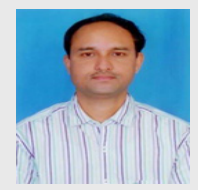

Amber Bharti completed his Master's Degree in science in 2003. He has around 18 years of experience in Analytical Research Development division in Major Pharmaceutical Companies. He is a doctoral student at Amity University, Uttar Pradesh, Noida-201303, India.

Dr. Ravindra Motiram Kumbhare received his PhD in Organic Chemistry from Rashtrasant Tukadoji Maharaj Nagpur University, Nagpur (India) under the supervision of Dr V. N.Ingle. Presently he is working as Principal Scientist at CSIR-Indian Institute of Chemical Technology, Hyderabad (India). His research focused on process developments of various fluorochemicals, fluorinated heterocycles of biological interest, multicomponent reaction and there analytical technique. He guided 05 students for the award of $\mathrm{PhD}$ degree and 02 students are still working and also guided $20 \mathrm{MSc}$ and B Pharmacy dissertation students. He published more than 35 research papers in national and international journal.

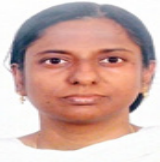

Dr. Christine Jeyaseelan is Associate Professor, Head of Department Chemistry at Amity Institute of Applied Sciences, Amity University, Noida. She has been awarded with doctoral degree by Nagpur University and is working in the field of electro-analytical and environmental chemistry, drug analysis and impurity studies. She has also written 2 books and has published several papers in national and international journals. She has 3 patents to her credit. She has more than 17 years of teaching experience.

Cite this article: Bharti A, Kumbhare RM, Jeyaseelan C. HPLC Method Development and Validation for the Quantification of Related Impurities in Testosterone Cypionate Active Pharmaceutical Ingredient. Indian $\mathrm{J}$ of Pharmaceutical Education and Research. 2022;56(1):240-6. 